\title{
Catalytic and Biological Activity of Silver and Gold Complexes Stabilized by NHC with Hydroxy Derivatives on Nitrogen Atoms
}

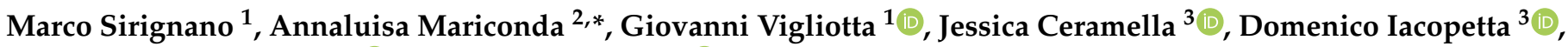 \\ Maria Stefania Sinicropi ${ }^{3}$ (D) and Pasquale Longo ${ }^{1}$ (D) \\ 1 Department of Chemistry and Biology, University of Salerno, Via Giovanni Paolo II, 132, 84084 Fisciano, Italy \\ msirignano@unisa.it (M.S.); gvigliotta@unisa.it (G.V.); plongo@unisa.it (P.L.) \\ 2 Department of Science, University of Basilicata, Viale dell'Ateneo Lucano 10, 85100 Potenza, Italy \\ 3 Department of Pharmacy, Health and Nutritional Sciences, University of Calabria, Via P. Bucci, \\ 87036 Arcavacata di Rende, Italy; jessica.ceramella@unical.it (J.C.); domenico.iacopetta@unical.it (D.I.); \\ s.sinicropi@unical.it (M.S.S.) \\ * Correspondence: annaluisa.mariconda@unibas.it; Tel.: +39-0971205932
}

\section{check for}

updates

Citation: Sirignano, M.; Mariconda,

A.; Vigliotta, G.; Ceramella, J.;

Iacopetta, D.; Sinicropi, M.S.; Longo, P. Catalytic and Biological Activity of Silver and Gold Complexes Stabilized by NHC with Hydroxy Derivatives on Nitrogen Atoms. Catalysts 2022, 12, 18. https://doi.org/10.3390/ catal12010018

Academic Editor: Laura

Antonella Aronica

Received: 18 November 2021

Accepted: 21 December 2021

Published: 25 December 2021

Publisher's Note: MDPI stays neutral with regard to jurisdictional claims in published maps and institutional affiliations.

Copyright: () 2021 by the authors. Licensee MDPI, Basel, Switzerland. This article is an open access article distributed under the terms and conditions of the Creative Commons Attribution (CC BY) license (https:// creativecommons.org/licenses/by/ $4.0 /)$.

\begin{abstract}
In this paper is reported the synthesis of $N, N^{\prime}$ hydroxy derivative of NHC silver (3a-4a) and gold(I) $(\mathbf{3 b}-\mathbf{4 b})$ complexes of general formula $\left[\mathrm{M}(\mathrm{NHC})_{2}\right]^{+}\left[\mathrm{MX}_{2}\right]^{-}$. All compounds were characterized by spectroscopic and analytic techniques. The complexes turned out to be effective in both catalytic and biological applications. They catalyzed the coupling of aldehyde, piperidine, and phenylacetylene in $\mathrm{A}^{3}$-reaction to produce propargylamines and showed antimicrobial activity. In fact, minimal inhibition concentration (MIC) tests with Gram-positive and Gram-negative bacteria demonstrated that the silver compounds are selective toward E. coli, whereas the gold analogues are active against $S$. aureus. Moreover, the $N, N^{\prime}$ hydroxy derivative of NHC silver complexes $3 \mathbf{a}$ and $4 \mathbf{a}$ exhibited good anticancer activity on the HeLA cancer cells $\left(3 \mathrm{a}-\mathrm{IC}_{50}=12.2 \pm 0.1 \mu \mathrm{M}\right.$, $\left.4 \mathrm{a}-\mathrm{IC}_{50}=11.9 \pm 1.2 \mu \mathrm{M}\right)$, whereas gold complex $4 \mathrm{~b}$ displayed good anticancer activity towards the MCF-7 cells $\left(\mathrm{IC}_{50}=12.2 \pm 1.2 \mu \mathrm{M}\right)$.
\end{abstract}

Keywords: NHC silver and gold complexes; coupling-catalysis; cytotoxic activity

\section{Introduction}

N-heterocyclic carbenes (NHCs) are nucleophilic compounds widely studied for their strong coordination ability as ancillary ligands of transition metals (M-NHCs) [1]. Their properties (steric and electronic) can be easily modulated, varying the substituents on the backbone and/or on the nitrogen atoms within the cyclic structure [1,2]. This versatility has made them suitable ligands in metal complexes, capable of catalysis [3-5] and medicinal applications [6-8].

Among the many transition elements stabilized by these ligands, coinage metals play an important role. They have proved to be useful activators in homogeneous catalysis for the hydrofunctionalization of allenes [9], alkenes [10] and alkynes [11], cycloisomerisations of enynes and ynones [12], C-H activation [13], and other organic transformations [14], as well as carbene transfer reactions [15]. Furthermore, in the past 15 years, the Ag(I) and $\mathrm{Au}(\mathrm{I}) \mathrm{NHC}$-complexes have been studied in the catalysis of new and, until then, unexplored reactions $[14,16]$. NHC-Ag complexes have been tested in reactions of diboration of alkenes [17], in the 1,3-dipolar cycloadditions of azomethine ylides with prop-2-enoates [18], in the cyclopropanation reactions between styrene and phenyldiazoacetate [19] and in the Sonogashira coupling of phenylacetylene and 4-iodoacetophenone [20].

NHC-Au complexes have been studied for addition of nucleophiles (water [21,22], alcohols [23], and amines [11]) to non-activated alkynes, in the $\mathrm{A}^{3}$-coupling reactions [24], and in the carboxylation of propargylamines to yield 2-oxazolidinones [25]. These $\mathrm{Au}$ 
and Ag NHC-complexes are stable to air and moisture, and this allows them to be tested also in the pharmacological fields $[26,27]$. Thus, many of them have proved to be effective anticancer and important antibacterial agents.

The use of silver and gold compounds have a long history in medicine [28,29]. Silver nitrate and silver sulfadiazine are used as antibacterials. The mechanism of action suggests that silver ions bind DNA by interfering with the body's intermediate metabolic pathway. Auranofin (1-thio- $\beta$-D-glucopyranosatotriethylphosphine gold-2,3,4,6-tetraacetate) is used to treat rheumatoid arthritis and has also shown important results in tests as an anticancer agent [26].

In this paper, we report the synthesis, characterization, and catalytic, antimicrobial, and antitumoral activities of new NHC silver(I) and gold(I) complexes (3a-b, $\mathbf{4 a - b})$. The synthesized complexes have a hydroxyl function on each of the nitrogen atoms of the imidazole ring that are soluble in green solvents such as water, thus widening the possibility of use, and they are more soluble in physiological environments, allowing a facile biological application. The catalytic activity of the complexes was verified in the three-component coupling reactions $\left(\mathrm{A}^{3}\right.$-coupling). The study of these kinds of reactions began at the end of the 1990s by Dax [30] and Rivero [31]. They assessed that, using carbophilic late transition metals, it was possible to activate olefins and alkynes by coordination to the metal center. The alkynes resulted active in $\mathrm{A}^{3}$-coupling reactions, which are multicomponent reactions (MCR) among aldehydes, amines, and alkynes, in a one pot manner to give propargylamine products containing almost all atoms of the substrate molecules and having as by-product only water [24,32]. It should be noted that this process is very interesting due to its sustainability and also for the numerous applications of propargylamines [33], i.e., they are important nitrogen-containing intermediates for the synthesis of various molecules that also pharmacologically active, such as Seleginine and Rasagiline, used to treat symptoms in early Parkinson's disease [34], and Ladostigil, a known neurodegenerative agent [35].

The antibacterial activity of all the synthesized complexes (3a-b, $\mathbf{4} \mathbf{a}-\mathbf{b})$ was determined against Gram-positive and Gram-negative bacteria. When similar metal complexes are used, this activity may depend on metal cations, which can bind to the cell membrane, to thiol groups of bacterial enzymes, or act by interfering with the mitochondrial electron transport system [36]. The anticancer activity was evaluated on MCF-7 and HeLa, which are human breast and cervical cancer cells, respectively. Furthermore, the complexes were tested on two normal cells, i.e., the human non-malignant breast epithelial MCF-10A and the embryonic kidney HEK-293 cells, and all compounds were non-cytotoxic, at least at doses up to $200 \mu \mathrm{M}$. The obtained results make these compounds interesting tools in different emerging areas, such as catalysis and medicinal chemistry, due to their easy synthesis and versatility.

It is worth noting that some of us, in previous work, have already carried out a study of the catalytic [37] and biological [38-40] behavior of similar silver and gold complexes bearing NHC ligands (see Figure 1), obtaining very interesting results.

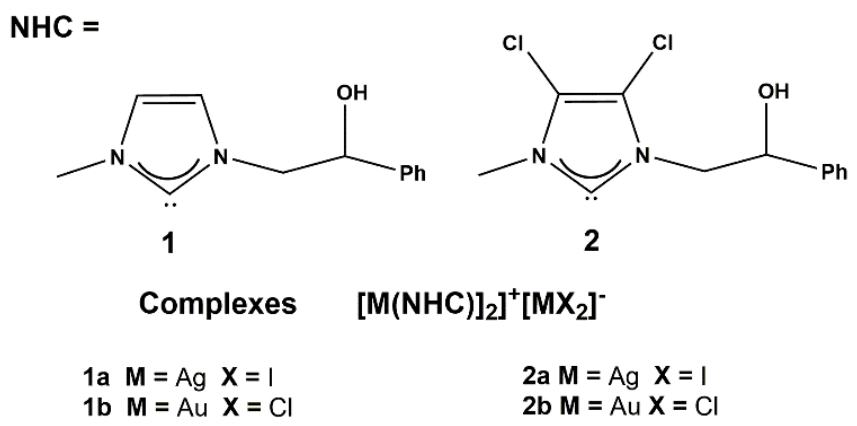

Figure 1. Recently reported NHC silver(I) and gold(I) complexes. 


\section{Results and Discussion}

\subsection{Synthesis and Characterization}

The NHC metal complexes, represented in Figure 2, were synthesized by slight changes of the literature procedure [37-43]

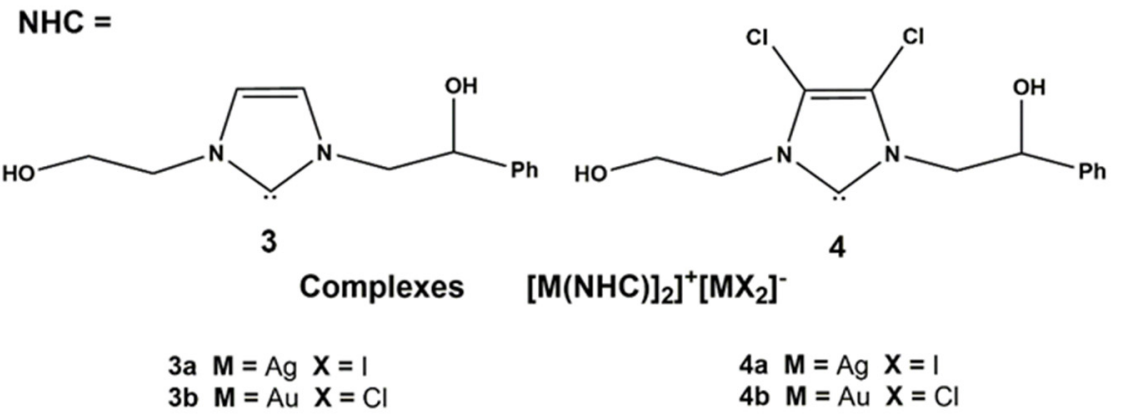

Figure 2. NHC ligands (3-4) and silver(I) (3a-4a) and gold(I) (3b-4b) complexes synthesized in this work.

The synthetic route to obtain $N$-heterocyclic carbene complexes $\mathbf{3 a}, \mathbf{3 b} \mathbf{b} \mathbf{4 a}$, and $\mathbf{4} \mathbf{b}$ is depicted in Scheme 1. The first step is the synthesis of two imidazolium salts (S3 and S4) containing different substituents on the backbone $(\mathrm{R}=\mathrm{H}$ for $\mathrm{S} 3$ or $\mathrm{R}=\mathrm{Cl}$ for $\mathrm{S} 4)$. They were achieved by reaction of imidazole or 4,5-dichloro imidazole with phenylethylene oxide followed by addition of 2-iodoethanol (see Scheme 1).

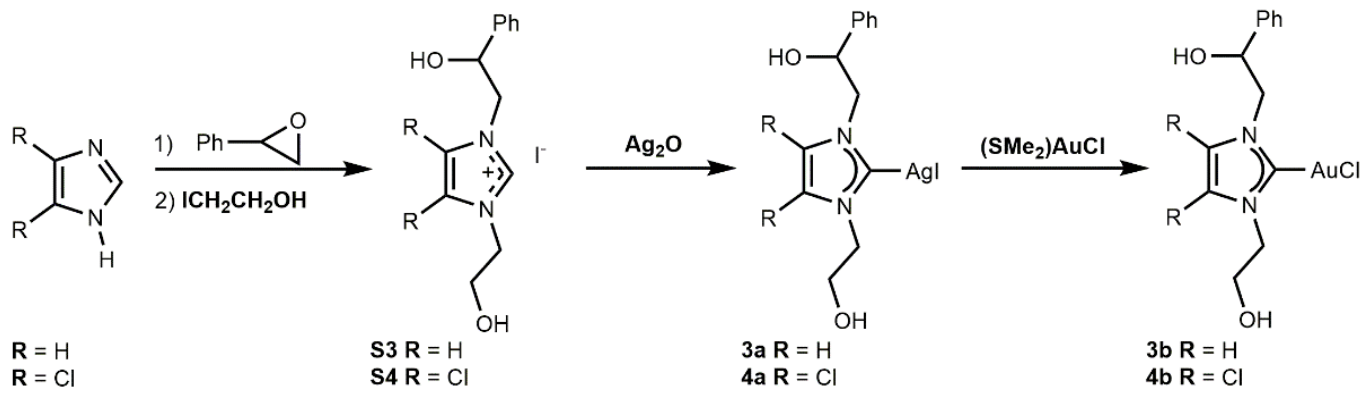

Scheme 1. Synthesis of NHC silver(I) and gold(I) complexes $\mathbf{3 a}, \mathbf{3 b}, \mathbf{4 a}$, and $\mathbf{4 b}$.

The obtained salts S3 and S4 were characterized by ${ }^{1} \mathrm{H}$ - and ${ }^{13} \mathrm{C}-\mathrm{NMR}$ analysis and by mass spectrometry. In ${ }^{1} \mathrm{H}-\mathrm{NMR}$ spectra, the signals of the protons on carbocationic (NCHN protons) of S3 and S4 are at $9.12 \mathrm{ppm}$ and $9.51 \mathrm{ppm}$, respectively. In ${ }^{13} \mathrm{C}$ NMR spectra, the resonance of NCHN carbocationics are at $136.75 \mathrm{ppm}$ and $137.39 \mathrm{ppm}$ for S3 and S4, respectively. The mass spectra (MALDI) of S3 show singlet signals at 233.12898, whereas $\mathbf{S} 4$ show multiplet signals having the main peak at 301.05142 Dalton, attributable to $\left[\mathrm{C}_{13} \mathrm{H}_{17} \mathrm{~N}_{2} \mathrm{O}_{2}\right]^{+}$and $\left[\mathrm{C}_{13} \mathrm{H}_{15} \mathrm{Cl}_{2} \mathrm{~N}_{2} \mathrm{O}_{2}\right]^{+}$that represent the cationic portions of imidazolium salts. The reaction of $\mathbf{S} 3$ or $\mathbf{S} 4$ salts with silver oxide $\left(\mathrm{Ag}_{2} \mathrm{O}\right)$ produced the corresponding silver(I) complexes $\mathbf{3 a}$ and $\mathbf{4 a}$ (see Scheme 1). They were characterized by NMR spectroscopy, ESI-MS spectrometry, and elemental analysis. The ${ }^{1} \mathrm{H}$ and ${ }^{13} \mathrm{C}$ NMR spectra show all the expected signals. In the ${ }^{1} \mathrm{H}-\mathrm{NMR}$ spectra, the absence of the signal attributable to the proton on $\mathrm{NCHN}$ carbocation demonstrated that the deprotonation reaction by silver oxide with formation of carbene has taken place $[14,15]$. The formation of 3a silver complex is confirmed in the ${ }^{13} \mathrm{C}$-NMR spectrum by the presence of a doublet attributable to $\mathrm{C}_{\text {carbene }}$ NCN-Ag. This type of signal is due to the coupling constant of $\mathrm{C}_{\text {carbene }}$ and $\mathrm{Ag}$, whose two naturally isotopes $\left({ }^{107} \mathrm{Ag} 51.839 \%\right.$ and ${ }^{109} \mathrm{Ag} 48.161 \%$ ) are both NMR active, having nuclear spin $\frac{1}{2}$. For $3 a$ the coupling constants are $182.3 \mathrm{~Hz}$ and $209.1 \mathrm{~Hz}$, respectively. Thus, the mass spectrum of $\mathbf{3 a}$ (ESI-MS) shows two signals of almost the same intensity attributable to $\left[\mathrm{C}_{26} \mathrm{H}_{32} \mathrm{AgN}_{4} \mathrm{O}_{4}\right]^{+}$, corresponding to $\left[(\mathrm{NHC})_{2} \mathrm{Ag}\right]^{+}$. The multiplicity of 
signals is due to nearly equal natural abundance of two isotopes of silver $\left({ }^{107} \mathrm{Ag}\right.$ and ${ }^{109} \mathrm{Ag}$ ) [44]. The ${ }^{13} \mathrm{C}-\mathrm{NMR}$ spectrum of $4 \mathbf{a}$ shows all the expected signals and a sharp signal attributable to carbene carbon bonded to silver atom $\left(\mathrm{C}_{\text {carbene }}-\mathrm{Ag}\right)$ at $183.67 \mathrm{ppm}$. It is worth noting that in literature are reported three cases for the pattern resonance of the carbene carbons bonded to silver $\left(\mathrm{C}_{\text {carbene }}-\mathrm{Ag}\right.$ ), i.e., (i) doublet of doublets (coupling constants of each silver isotope ${ }^{107} \mathrm{Ag}$ and ${ }^{109} \mathrm{Ag}$ ); (ii) no splitting pattern (sharp or broad singlet); and (iii) no observation of the carbenic peak [44]. The ESI-MS spectrum of $4 a$ shows more signals attributable to a bis-carbene structure $\left[\mathrm{C}_{26} \mathrm{H}_{28} \mathrm{AgCl}_{4} \mathrm{~N}_{4} \mathrm{O}_{4}\right]^{+}$. In this case the multiplicity of signals is attributable to the presence of both silver isotopes $\left({ }^{107} \mathrm{Ag}\right.$ and $\left.{ }^{109} \mathrm{Ag}\right)$ and chlorine $\left({ }^{35} \mathrm{Cl}\right.$ and $\left.{ }^{37} \mathrm{Cl}\right)$. The elemental analysis for two complexes shows a relationship between ligand, silver, and iodide of 1:1:1, so that it is reasonable to assume for both complexes a structure of the type $\left[(\mathrm{NHC})_{2} \mathrm{Ag}\right]^{+}\left[\mathrm{AgI}_{2}\right]^{-}$. Whereby, silver complexes $3 \mathrm{a}$ and $4 \mathbf{a}$, according to mass and elemental analysis, are present as $\left[(\mathrm{NHC})_{2} \mathrm{Ag}\right]^{+}$cation and reasonably $\left[\mathrm{AgI}_{2}\right]^{-}$as counter-ion. The proposed structure was observed in solid state for similar silver complexes by X-ray diffraction analysis from both Lin [15] and by some of us [45].

The gold complexes $\mathbf{3 b}$ and $\mathbf{4 b}$ were synthesized via trans-metalation (see Scheme 1 ) by reaction of silver complex $3 \mathbf{a}$ or $4 \mathbf{a}$ with dimethylsulfide-gold(I)-chloride at room temperature and with exclusion of light. The two gold complexes were obtained as light-yellow powder in a good yield: $40 \%$ for $\mathbf{3 b}$ and $61 \%$ for $\mathbf{4 b}$. The complexes were characterized by ${ }^{1} \mathrm{H}-\mathrm{NMR},{ }^{13} \mathrm{C}-\mathrm{NMR}$, mass spectrometry (MALDI-MS), and elemental analysis. The ${ }^{13} \mathrm{C}-\mathrm{NMR}$ spectra of $\mathbf{3 b}$ and $\mathbf{4 b}$ show sharp signals for carbene carbon at 168.37 and 170.90 ppm, respectively. Mass spectra show a peak at 661.2110 for $3 \mathrm{~b}$ and 709.05720 for $4 \mathrm{~b} m / z$, attributable to a bis-carbene structure. All the complexes are moisture and light stable; when solubilized in DMSO/ $\mathrm{D}_{2} \mathrm{O}(90 / 10)$ and exposed to light for $24 \mathrm{~h}$ at room temperature, they did not show any changes in ${ }^{1} \mathrm{H}-\mathrm{NMR}$ spectra. The elemental analysis for two complexes shows a relationship between ligand, gold, and chloride of 1:1:1, so that it is reasonable to assume also for gold(I) complexes a structure of the type $\left[(\mathrm{NHC})_{2} \mathrm{Au}\right]^{+}\left[\mathrm{AuCl}_{2}\right]^{-}$. However, it is fair to suppose that for these complexes in solution there is an equilibrium between the ionic form $\left[\mathrm{M}(\mathrm{NHC})_{2}\right]^{+}\left[\mathrm{MX}_{2}\right]^{-}$and neutral form $\mathrm{M}(\mathrm{NHC}) \mathrm{X}$. Thus, conductibility measurements confirmed the electrolytic nature of the complexes; in fact, the conductance values of the compounds, measured in $\mathrm{CH}_{2} \mathrm{Cl}_{2}$, displayed a concentration dependence. Whereas it is obvious to believe that the neutral specie is present in solution because a gold complex in neutral form was recently isolated and characterized by $\mathrm{X}$-ray diffraction analysis, and this is the necessary form for catalytic activity [46].

\subsection{Catalytic Behavior in $A^{3}$-Coupling Reactions}

In literature, it is known that many metal complexes can catalyze the synthesis of important scaffolds [24,32], and recently, among them, $N$-heterocyclic carbene complexes of silver and gold have showed valuable catalytic activity in $\mathrm{A}^{3}$-coupling reactions $[37,46,47]$.

For this reason, the silver and gold complexes $3 \mathbf{a}, \mathbf{4 a}, \mathbf{3} \mathbf{b}$, and $\mathbf{4} \mathbf{b}$ were tested in $\mathrm{A}^{3}$ coupling reactions of aldehyde, amine, and alkyne to produce propargylamines (Scheme 2). They are an important class of organic compound precursor of drugs that act as neuromodulator of monoamine oxidases (MAO), which are a valuable class of mitochondrial enzymes with a critical role in the inhibitory activity of dopaminergic metabolism, i.e., pargyline, rasagyline, selegiline, that are used in the treatment of Alzheimer's and Parkinson's diseases [33-35].

In Table 1 we report the catalytic activities of the synthesized NHC silver and gold complexes using alkyne (phenylacetylene), secondary amine (piperidine), and three different aldehydes (p-formaldehyde, cyclohexanecarboxaldehyde, and benzaldehyde) at $80{ }^{\circ} \mathrm{C}$ to obtain PAA1, PAA2, and PAA3. 


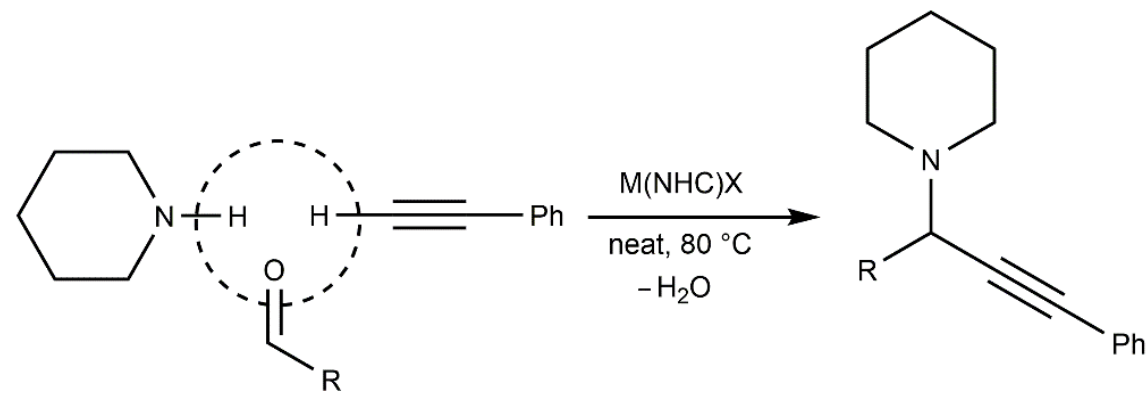

$\mathbf{R}=\mathrm{H}, \mathrm{Cy}, \mathrm{Ph}$

Scheme 2. $\mathrm{A}^{3}$-coupling reaction to give propargylamine PAA (PAA1 where $\mathrm{R}=\mathrm{H}$; PAA2 where $\mathrm{R}=$ cyclohexyl; PAA3 where $\mathrm{R}$ = phenyl).

Table 1. Catalytic activity of $\mathrm{Ag}-\mathrm{NHC}$ and $\mathrm{Au}-\mathrm{NHC}$ in $\mathrm{A}^{3}$-coupling reactions.

\begin{tabular}{|c|c|c|c|c|}
\hline $\operatorname{Run}^{a}$ & Catalyst & Aldehyde & Products & Yield $^{\mathrm{b}}(\%)$ \\
\hline 1 & \multirow{3}{*}{$3 a$} & p-formaldehyde & PAA1 & 25 \\
\hline 2 & & cyclohexanecarboxaldehyde & PAA2 & 47 \\
\hline 3 & & benzaldehyde & PAA3 & 23 \\
\hline 4 & \multirow{3}{*}{$4 a$} & p-formaldehyde & PAA1 & 65 \\
\hline 5 & & cyclohexanecarboxaldehyde & PAA2 & 52 \\
\hline 6 & & benzaldehyde & PAA3 & 36 \\
\hline 7 & \multirow{3}{*}{$3 b$} & p-formaldehyde & PAA1 & 86 \\
\hline 8 & & cyclohexanecarboxaldehyde & PAA2 & 65 \\
\hline 9 & & benzaldehyde & PAA3 & 60 \\
\hline 10 & \multirow{3}{*}{$4 b$} & p-formaldehyde & PAA1 & 99 \\
\hline 11 & & cyclohexanecarboxaldehyde & PAA2 & 99 \\
\hline 12 & & benzaldehyde & PAA3 & 60 \\
\hline
\end{tabular}

a Reaction conditions: aldehyde (1.0 mmol), piperidine (1.2 mmol), phenylacetylene $(1.5 \mathrm{mmol}),(\mathrm{NHC})_{2}-\mathrm{M}$ catalyst $(3 \mathrm{~mol} \%), 80^{\circ} \mathrm{C}$, nitrogen atmosphere, 6 h. ${ }^{\mathrm{b}}$ Conversions were determined by ${ }^{1} \mathrm{H}-\mathrm{NMR}$ analysis (internal standard: 2-bromo mesitylene).

The reactions were carried out without the use of solvents, and the results were very interesting also from the point of view of sustainable chemistry. The yields were determined using ${ }^{1} \mathrm{H}-\mathrm{NMR}$ analysis, by integration of the singlet signal of internal standard (2-bromomesytilene) at $6.89 \mathrm{ppm}$ in $\mathrm{CD}_{2} \mathrm{Cl}_{2}$, with the signal of propargylic product $(\delta 3.43$ ppm for $\mathrm{N}$-(3-phenyl-2-propynyl) piperidine, PAA1, $\delta 3.11 \mathrm{ppm}$ for $\mathrm{N}$-(1-cyclohexyl-3phenyl-2-propynyl) piperidine, PAA2, $\delta 4.79$ ppm for PAA3 $N$-(1,3-diphenyl-2-propynyl) piperidine).As shown in Table 1, all complexes are capable of catalyzing the coupling of aldehyde, piperidine, and phenylacetylene. Silver complexes are less active than analog gold complexes (compare runs 1-3 with 7-9 and 4-6 with 10-12). Complexes 3a and 4a, which have $\mathrm{N}$-heterocyclic carbene with hydrogens on the backbone, are less active than silver and gold complexes $3 \mathrm{~b}$ and $4 \mathrm{~b}$ with chlorine atoms on the backbone (compare runs 1-6 with 7-12). The greatest activity of complexes bearing a NHC ligand with two chlorine atoms on the backbone was also found in our previous work [37].

It was attributable to a major positive charge on the metal center, which makes it more electrophilic and more active to coordinate the phenylacetylene. Moreover, benzaldehyde is less reactive with respect to aliphatic aldehydes.

\section{Biological Activities}

\subsection{Antibacterial Activity}

The antibacterial activity of compounds containing Ag ( $3 a$ and $4 a)$ and $A u(3 b$ and $4 \mathbf{b}$ ) were assessed by determining the MIC (minimal inhibitory concentration) according to the CLSI (Clinical and Laboratory Standards Institute) guidelines [48,49]. The compounds 
were tested against both Gram positive Staphylococcus aureus and Gram-negative bacteria Escherichia coli. Another analog molecule, 1a, previously demonstrated effective on E. coli [40] and pro-ligands S1, S2, S3, S4 were also introduced as experimental controls [40]. We have also tested the analog gold complex $\mathbf{1} \mathbf{b}$ and, furthermore, the $\mathbf{2} \mathbf{a}$ and $\mathbf{2} \mathbf{b}$, which have chlorine on the backbone of the imidazole ring instead of hydrogen. Results are shown in Table 2. Compounds containing Ag were very effective on E. coli, with MIC values between 10 and $15 \mu \mathrm{g} / \mathrm{mL}$, whereas, except for $3 a$ (MIC $50 \mu \mathrm{g} / \mathrm{mL}$ ), up to the maximum concentration tested $(150 \mu \mathrm{g} / \mathrm{mL})$ they had no effect on the growth of $S$. aureus. As expected, 1a exhibited high antimicrobial action against the tested strain of E. coli (MIC $6.5 \mu \mathrm{g} / \mathrm{mL}$ ). On the contrary, all molecules containing Au were very efficient against the Gram-positive S. aureus, with very low MIC values. In particular, $\mathbf{2 b}$ showed a minimum inhibition dose of $0.5 \mu \mathrm{g} / \mathrm{mL}$. Unlike the compounds with $\mathrm{Ag}$, the $\mathrm{Au}$ complexes were active towards both bacteria species. In fact, except for $\mathbf{1 b}(\mathrm{MIC}>15 \mu \mathrm{g} / \mathrm{mL})$, all showed a fair antimicrobial activity towards Gram-negative (MIC 75-100 $\mu \mathrm{g} / \mathrm{mL}$ ), indicating for these latter properties of broader spectrum antimicrobials. For both bacterial genera, the pro-ligands S1-S4 showed no growth inhibition effect up to the tested concentration of $200 \mu \mathrm{g} / \mathrm{mL}$.

Table 2. Antimicrobial activity tested on representative Gram negative and positive bacteria.

\begin{tabular}{|c|c|c|}
\hline \multirow{2}{*}{ Complex } & \multicolumn{2}{|c|}{ MIC (Minimal Inhibitory Concentration) $\mu \mathrm{g} / \mathrm{mL}(\mu \mathrm{M})^{a}$} \\
\hline & E. Coli (Gram Negative) & S. Aureus (Gram Positive) \\
\hline $1 a^{b}$ & $6.5(14.9)$ & $>150(>343.2)$ \\
\hline $2 \mathbf{a}$ & $10(19.8)$ & $>150(>296.4)$ \\
\hline 3a & $15(32.1)$ & $50(107.0)$ \\
\hline $4 a$ & $15(27.9)$ & $>150(>279.8)$ \\
\hline $1 b$ & $>150(>345.1)$ & $40(92.0)$ \\
\hline $2 b$ & $75(148.9)$ & $0.5(0.99)$ \\
\hline $3 b$ & $100(215.2)$ & $25(53.8)$ \\
\hline $4 b$ & 75 (140.7) & $2.5(4.7)$ \\
\hline
\end{tabular}

Reported values were determined by three independent assays, each in triplicate. ${ }^{\text {a }} 150 \mu \mathrm{g} / \mathrm{mL}$ is the highest concentration tested for each compound. ${ }^{\mathrm{b}}$ Complex $1 \mathrm{a}$ was introduced as experimental control active versus E. coli strains.

\subsection{Anticancer Activity}

The complex 1a was characterized as in rif. [40]. The Ag complexes 3a and 4a and $\mathrm{Au}$ complexes $\mathbf{3 b}$ and $\mathbf{4 b}$ were evaluated for their anticancer activity towards two human breast cancer cell lines, namely MCF-7 and MDA-MB-231 cells, and the human cervix carcinoma HeLa cells. As shown in Table 3, where the $\mathrm{IC}_{50}$ values are listed, the silver complexes were more active compared to the gold ones. In particular, the Ag complexes $3 \mathbf{a}$ and $\mathbf{4 a}$ exerted the best anticancer activity towards the HeLa cells, possessing a comparable activity with $\mathrm{IC}_{50}$ values of $12.2 \pm 1.0 \mu \mathrm{M}$ for $3 \mathbf{a}$ and $11.9 \pm 0.4 \mu \mathrm{M}$ for $4 \mathbf{a}$. These compounds also exhibited good anticancer activity on the MCF-7 cells, but to a lower extent when compared to that displayed on HeLa cells, with $\mathrm{IC}_{50}$ values of $20.3 \pm 1.1 \mu \mathrm{M}$ and $19.5 \pm 0.9 \mu \mathrm{M}$, respectively. In contrast, $\mathrm{Au}$ complexes showed no anticancer activity in all the cancer cell lines tested, at least until the concentration reached $200 \mu \mathrm{M}$, except for Au complex $\mathbf{4 b}$ that exhibited a good anticancer activity towards the MCF-7 cells $\left(\mathrm{IC}_{50}=12.2 \pm 1.2 \mu \mathrm{M}\right)$ and a very low activity on the triple negative MDA-MB-231 cells $\left(\mathrm{IC}_{50}=49.5 \pm 0.7 \mu \mathrm{M}\right)$. None of the gold-based complexes ( $3 \mathbf{b}$ and $\mathbf{4 b}$ ) were found to be active against HeLa. Moreover, we verified whether the pro-ligands by themselves could exert a cytotoxic activity on the same cancer cells. As a result, neither $\mathbf{S} 3$ nor $\mathbf{S} 4$ exerted anticancer effects, at least at doses equal to or below $200 \mu \mathrm{M}$. Once established that some of the new synthesized complexes possess interesting antibacterial and antitumor activities, we tested all the compounds on two human normal cells, the breast epithelial MCF-10A cells, and the embryonic kidney cells Hek-293, in order to determine their cytotoxic effect. The obtained results showed that none of the Au and Ag complexes affected the viability of the used normal cells up to 
$200 \mu \mathrm{M}$. The silver complexes were more active than Cisplatin, a well-known anticancer drug used as reference molecule [39]. Indeed, Cisplatin was able to reduce MCF-7 and HeLa cells viability with $\mathrm{IC}_{50}$ values of $36.2 \pm 1.0 \mu \mathrm{M}$ and $16.2 \pm 1.1 \mu \mathrm{M}$, respectively. Moreover, each metal complex did not affect the viability of the two normal cell lines, in contrast to Cisplatin, which showed a strong cytotoxicity $\left(\mathrm{IC}_{50}=80.7 \pm 1.0 \mu \mathrm{M}\right.$ on MCF-10A and $16.1 \pm 0.9 \mu \mathrm{M}$ on Hek-293).

Table 3. $\mathrm{IC}_{50}$ values of the studied metal complexes (3a,b and $\left.\mathbf{4 a , b}\right)$ and the ligands (S3 and S4) expressed in $\mu \mathrm{M}$.

\begin{tabular}{cccccc}
\hline Sample & MDA-MB-231 & $\begin{array}{c}\text { IC }_{\mathbf{5 0}}(\boldsymbol{\mu M}) \\
\text { MCF-7 }\end{array}$ & HeLa & MCF-10A & Hek-293 \\
\hline S3 & $>200$ & $>200$ & $>200$ & $>200$ & $>200$ \\
S4 & $>200$ & $>200$ & $>200$ & $>200$ & $>200$ \\
3a & $>200$ & $20.3 \pm 1.1$ & $12.2 \pm 1.0$ & $>200$ & $>200$ \\
3b & $>200$ & $>200$ & $>200$ & $>200$ & $>200$ \\
4a & $>200$ & $19.5 \pm 0.9$ & $11.9 \pm 0.4$ & $>200$ & $>200$ \\
4b & $49.5 \pm 0.7$ & $12.2 \pm 1.2$ & $>200$ & $>200$ & $>200$ \\
Cisplatin & $28.9 \pm 0.7$ & $36.2 \pm 1.0$ & $16.2 \pm 1.1$ & $80.7 \pm 1.0$ & $16.1 \pm 0.9$ \\
\hline
\end{tabular}

\section{Experimental Design}

\subsection{Materials and Methods}

All synthesis, manipulations, and characterization experiments were carried out under an oxygen and moisture free atmosphere using Schlenk techniques. Reagents were purchased from Sigma Aldrich and TCI Chemicals and used without any other operation of purification. Solvents were degassed and dehydrated under a nitrogen atmosphere by heating at reflux over suitable drying agents. NMR solvents (Euriso-Top products) were kept out of the light over molecular sieves. NMR spectra were recorded on Brucker AM 300 spectrometers (300 MHz for ${ }^{1} \mathrm{H} ; 75 \mathrm{MHz}$ for ${ }^{13} \mathrm{C}$ ) and a Brucker AVANCE 400 spectrometer $\left(400 \mathrm{MHz}\right.$ for ${ }^{1} \mathrm{H} ; 100 \mathrm{MHz}$ for $\left.{ }^{13} \mathrm{C}\right)$. The samples were prepared by dissolving $20 \mathrm{mg}$ of compounds in $0.6 \mathrm{~mL}$ of deuterated solvent. The chemical shifts of ${ }^{1} \mathrm{H}-\mathrm{NMR}$ and ${ }^{13} \mathrm{C}-\mathrm{NMR}$ spectra are referenced to tetramethylsilane ( $\left.\mathrm{SiMe}_{4}, \delta=0 \mathrm{ppm}\right)$. The spectrum multiplicities are abbreviated in this manner: singlet (s), doublet $(\mathrm{d})$, triplet $(\mathrm{t})$, multiplet (m), and broad (br).

The elementary analyses for $\mathrm{C}, \mathrm{H}$, and $\mathrm{N}$ were performed according to standard microanalytical procedures, recording them by means of a Thermo-Finnigan Flash EA 1112.

The determination of the quantities of chloride and iodide was performed indirectly by reaction of $\mathrm{AgNO}_{3}$ with the halogen and precipitation of the silver halide (AgX). It was dissolved with $\mathrm{Na}_{2} \mathrm{~S}_{2} \mathrm{O}_{3}$, and the silver content in the solution was determined by atomic flame absorption spectroscopy (FAAS), achieving the halogen content from the amount of silver. The mass of the organic compounds was determined by ESI-MS with a Waters Quattro Micro triple quadrupole mass spectrometer furnished with an electrospray ion source.

ESI-FT-ICR measurements of the complexes were carried out using a Bruker Solaris XR instrument. MALDI-MS mass spectra were recorded using a Bruker SolariX (Bruker Daltonik GmbH, Bremen, Germany) Fourier transform ion cyclotron resonance mass spectrometer equipped with a refrigerated $7 \mathrm{~T}$ actively shielded superconducting magnet (Bruker Biospin, Wissembourg, France). The samples were positively ionized using the MALDI ion source (Bruker Daltonik $\mathrm{GmbH}$, Bremen, Germany). The laser power was $28 \%$, and 22 laser shots were used for each scan. The mass range was set to $m / z 200-3000$. The mass spectra were calibrated externally, applying linear calibration and using a mix of peptide clusters in MALDI positive ionization mode. To improve the accuracy of the measurement, the spectra of the samples were recalibrated internally by matrix ionization (2,5-dihydroxybenzoic acid). 


\subsection{Synthesis}

4.2.1. General Procedure for Synthesis of N-Heterocyclic Carbene Proligands (S3 and S4)

Imidazolium salts S3 and S4 were synthesized following the synthetic strategy by Arnold and coworkers [41,42] and applying the procedures reported in literature by us $[37-40,45,46]$. Imidazole or 4,5-dichloro imidazole (1.0 eq) was reacted with phenylethylene oxide (1.2 eq) for $12 \mathrm{~h}$ at refluxing temperature, and subsequently 2-iodoethanol (2.0 eq) was added. The imidazolium salts were obtained by precipitation and washed with hexane $(3 \times 20 \mathrm{~mL})$ and diethyl ether $(3 \times 30 \mathrm{~mL})$.

\subsubsection{Synthesis of Iodo [N-(2-Hydroxyethyl)-N'-(2-Hydroxy-2-Phenyl)}

Ethyl-Imidazole-2-Ylidene] (S3)

Imidazole (1.00 g, $15.4 \mathrm{mmol})$ and phenylethylene oxide $(2.40 \mathrm{~g}, 18.5 \mathrm{mmol})$ were dissolved in $25 \mathrm{~mL}$ of $\mathrm{CH}_{3} \mathrm{CN}$ and stirred at refluxing temperature for $12 \mathrm{~h}$. Subsequently, the reaction mixture was cooled, and 2-iodoethanol $(5.29 \mathrm{~g}, 30.8 \mathrm{mmol})$ was added. The mixture was warmed up to refluxing temperature and stirred for $8 \mathrm{~h}$ more. The product was recovered by removing the solvent and precipitation in cold acetone. The resulting powder (5.73 g, $15.9 \mathrm{mmol}$, yield $86 \%)$ was washed with hexane $(3 \times 20 \mathrm{~mL})$ and diethyl ether $(2 \times 30 \mathrm{~mL})$.

${ }^{1} \mathrm{H}-\mathrm{NMR}\left(\delta\right.$ ppm, DMSO- $\left.d_{6}, 400 \mathrm{MHz}\right): 9.12(\mathrm{~s}, \mathrm{NCHN}, 1 \mathrm{H}), 7.75-7.35$ (m, aromatic hydrogens, 7H), $5.99(\mathrm{~d}, \mathrm{OH}, 1 \mathrm{H}), 5.17(\mathrm{~b}, \mathrm{OH}, 1 \mathrm{H}), 4.97(\mathrm{t}, \mathrm{CHOH}, 1 \mathrm{H}), 4.46-4.25(\mathrm{~m}$, $\left.\mathrm{NCH}_{2} \mathrm{CH}_{2} \mathrm{OH}, \mathrm{NCH}_{2} \mathrm{CHOH}, 4 \mathrm{H}\right), 3.75\left(\mathrm{~d}, \mathrm{NCH}_{2} \mathrm{CH}_{2} \mathrm{OH}, 2 \mathrm{H}\right)$. (in Supplementary Materials Figure S1)

${ }^{13} \mathrm{C}-\mathrm{NMR}\left(\delta \mathrm{ppm}, \mathrm{DMSO}-d_{6}, 100 \mathrm{MHz}\right): 141.28$ (ipso carbon of aromatic ring), $136.75(\mathrm{NCHN}), 128.34,127.82,125.99$ (aromatic carbons), 122.95, 122.28 (backbone carbons), $70.70(\mathrm{CHOH}), 59.36\left(\mathrm{CH}_{2} \mathrm{OH}\right), 55.60\left(\mathrm{NCH}_{2} \mathrm{CHOH}\right), 51.56\left(\mathrm{NCH}_{2} \mathrm{CH}_{2} \mathrm{OH}\right)$. (in Supplementary Materials Figure S2)

MALDI, $(m / z)$ : 233.12898 Dalton attributable to $\left[\mathrm{C}_{13} \mathrm{H}_{17} \mathrm{~N}_{2} \mathrm{O}_{2}\right]^{+}$. (in Supplementary Materials Figure S3)

\subsubsection{Synthesis of Iodo [4,5-Dichloro $N$-(2-Hydroxyethyl) $-N^{\prime}-(2-H y d r o x y-2-P h e n y l)$} Ethyl-Imidazole-2-Ylidene] (S4)

Both 4,5-dichloro imidazole $(1.00 \mathrm{~g}, 7.33 \mathrm{mmol})$ and phenylethylene oxide $(1.32 \mathrm{~g}$, $11.0 \mathrm{mmol}$ ) were dissolved in $25 \mathrm{~mL}$ of $\mathrm{CH}_{3} \mathrm{CN}$ and stirred at refluxing temperature for $12 \mathrm{~h}$. Subsequently, the reaction mixture was cooled, and 2-iodoethanol $(2.52 \mathrm{~g}, 14.6 \mathrm{mmol})$ was added. The reaction mixture was warmed up to refluxing temperature and stirred for $8 \mathrm{~h}$ more. The product was recovered, removing the solvent and precipitation in cold acetone. The resulting powder $(1.88 \mathrm{~g}, 4.39 \mathrm{mmol}$, yield $60 \%)$ was washed with hexane $(3 \times 20 \mathrm{~mL})$ and diethyl ether $(2 \times 30 \mathrm{~mL})$.

${ }^{1} \mathrm{H}-\mathrm{NMR}\left(\delta \mathrm{ppm}, \mathrm{DMSO}-d_{6}, 400 \mathrm{MHz}\right): 9.51(\mathrm{~s}, \mathrm{NCHN}, 1 \mathrm{H}), 7.40-7.33$ (m, aromatic hydrogens, 5H), $6.05(\mathrm{~d}, \mathrm{OH}, 1 \mathrm{H}), 5.18(\mathrm{t}, \mathrm{OH}, 1 \mathrm{H}), 4.99(\mathrm{t}, \mathrm{CHOH}, 1 \mathrm{H}), 4.49-4.34(\mathrm{~m}$, $\left.\mathrm{NCH}_{2} \mathrm{CHOH}, \mathrm{NCH}_{2} \mathrm{CH}_{2} \mathrm{OH} ; 4 \mathrm{H}\right), 3.77\left(\mathrm{~d}, \mathrm{NCH}_{2} \mathrm{CH}_{2} \mathrm{OH}, 2 \mathrm{H}\right.$ ) (in Supplementary Materials Figure S4).

${ }^{13} \mathrm{C}-\mathrm{NMR}\left(\delta \mathrm{ppm}, \mathrm{DMSO}-d_{6}, 100 \mathrm{MHz}\right)$ : 140.44 (ipso carbon of aromatic ring), 137.39 (NCHN), 128.47, 128.10, 125.96 (aromatic carbons), 118.91, 118.47 (backbone carbons), 69.80 $(\mathrm{CHOH}), 58.18\left(\mathrm{CH}_{2} \mathrm{OH}\right), 54.85\left(\mathrm{NCH}_{2} \mathrm{CHOH}\right), 51.08\left(\mathrm{NCH}_{2} \mathrm{CH}_{2} \mathrm{OH}\right)$. (in Supplementary Materials Figure S5)

MALDI: $(m / z)$ : 301.05142 Dalton attributable to $\left[\mathrm{C}_{13} \mathrm{H}_{15} \mathrm{Cl}_{2} \mathrm{~N}_{2} \mathrm{O}_{2}\right]^{+}$(in Supplementary Materials Figure S6).

4.2.4. General Procedure for the Synthesis of Silver(I) N-Heterocyclic Carbene Complexes (3a and $\mathbf{4 a}$ )

The imidazolium salt S3 or $\mathbf{S} 4$ (1 eq) was suspended in dry-dichloromethane (25 mL) and molecular sieves $4 \AA$. $\mathrm{Ag}_{2} \mathrm{O}(0.7 \mathrm{eq})$ was added to mixture, and it was stirred for $4 \mathrm{~h}$ at room temperature with no light. It was then filtered on a pad of Celite to eliminate the 
silver iodide byproduct and the molecular sieves. The complexes ( $3 \mathbf{a}$ and $\mathbf{4 a}$ ) were obtained after the removal of the solvent in vacuo.

4.2.5. Synthesis of Iodo

[N-(2-Hydroxyethyl)- $N^{\prime}$-(2-Hydroxy-2-Phenyl)Ethyl-Imidazole-2-Yliden] Silver(I) (3a)

The silver complex 3a was obtained by reaction of imidazolium salt S3 (0.508 g; $1.41 \mathrm{mmol})$ and $\mathrm{Ag}_{2} \mathrm{O}(0.202 \mathrm{~g} ; 0.914 \mathrm{mmol})$ in dry dichloromethane $(25 \mathrm{~mL})$ in the presence of $4 \AA$ molecular sieves, at room temperature and in dark conditions for $4 \mathrm{~h}$. The reaction mixture was filtered by celite and solvent was evaporated in vacuo. The residual powder was washed by dry diethyl ether $(3 \times 30 \mathrm{~mL})$, and dried by reduced pressure to lead the silver complexes as a white powder $(0.330 \mathrm{~g}, 0.71 \mathrm{mmol}$, yield: $50 \%)$.

${ }^{1} \mathrm{H}-\mathrm{NMR}\left(\delta \mathrm{ppm}\right.$, DMSO- $\left.d_{6}, 400 \mathrm{MHz}\right): 7.38-7.31(\mathrm{~m}$, aromatic hydrogens, $7 \mathrm{H}), 5.88(\mathrm{~b}$, $\mathrm{CHOH}, 1 \mathrm{H}) 5.07\left(\mathrm{~b}, \mathrm{CH}_{2} \mathrm{OH}, 1 \mathrm{H}\right), 4.99\left(\mathrm{~b}, \mathrm{NCH}_{2} \mathrm{CHOH}, 1 \mathrm{H}\right), 4.33-4.27\left(\mathrm{~m}, \mathrm{NCH}_{2} \mathrm{CHOH}\right.$, $\left.\mathrm{NCH}_{2} \mathrm{CH}_{2} \mathrm{OH}, 4 \mathrm{H}\right), 3.73\left(\mathrm{~b}, \mathrm{NCH}_{2} \mathrm{CH}_{2} \mathrm{OH}, 2 \mathrm{H}\right.$ ) (in Supplementary Materials Figure S7).

${ }^{13} \mathrm{C}-\mathrm{NMR}\left(\delta \mathrm{ppm}, \mathrm{DMSO}-d_{6}, 100 \mathrm{MHz}\right): 181.23-179.28\left(\mathrm{dd},{ }^{1} \mathrm{~J}_{\mathrm{C}-107-\mathrm{Ag}}=182.3 \mathrm{~Hz}\right.$, ${ }^{1} \mathrm{~J}_{\mathrm{C}-109-\mathrm{Ag}}=209.1 \mathrm{~Hz}$ ), 142.53 (ipso carbon aromatic ring), 128.10, 127.10, 126.02 (aromatic carbons), $122.40,121.85$ (backbone carbons), $72.46(\mathrm{CHOH}), 61.19\left(\mathrm{CH}_{2} \mathrm{OH}\right), 58.40\left(\mathrm{NCH}_{2} \mathrm{CHOH}\right)$, $53.62\left(\mathrm{NCH}_{2} \mathrm{CH}_{2} \mathrm{OH}\right)$ (in Supplementary Materials Figure S8).

ESI-MS $\left(\mathrm{CH}_{3} \mathrm{CN}, \mathrm{m} / z\right)$ : $573.14690 \mathrm{Da}$ attributable to $\left[\mathrm{C}_{26} \mathrm{H}_{32} \mathrm{AgN}_{4} \mathrm{O}_{4}\right]^{+}$(in Supplementary Materials Figure S9).

4.2.6. Synthesis of Iodo [4,5-Dichloro $N$-(2-Hydroxyethyl) - $N^{\prime}$-(2-Hydroxy-2-Phenyl) Ethyl-Imidazole-2-Yliden] Silver(I) (4a)

The silver complex 4 a was synthesized by reaction of iodo [4,5-dichloro $N$-(2-hydroxyethyl) - $\mathrm{N}^{\prime}$-(2-hydroxy-2-phenyl) ethyl-imidazole-2-ylidene] ( $\left.0.530 \mathrm{~g} ; 1.23 \mathrm{mmol}\right)$ with silver oxide $(0.171 \mathrm{~g} ; 0.74 \mathrm{mmol})$ in dry dichloromethane $(25 \mathrm{~mL})$ in the presence of $4 \AA$ A molecular sieves at room temperature for $4 \mathrm{~h}$ in the dark. The reaction mixture was then filtered on a pad of Celite, the solvent was removed, and the residual powder was washed with dry diethyl ether $(3 \times 30 \mathrm{~mL})$ to give a light-yellow powder $(0.362 \mathrm{~g}, 0.677 \mathrm{mmol}$, yield: $55 \%)$.

${ }^{1} \mathrm{H}-\mathrm{NMR}\left(\delta \mathrm{ppm}\right.$, DMSO- $\left.d_{6}, 400 \mathrm{MHz}\right): 7.38-7.28(\mathrm{~m}$, aromatic hydrogens, $5 \mathrm{H}), 5.89(\mathrm{~s}$, $\mathrm{CHOH}, 1 \mathrm{H}), 5.07\left(\mathrm{~b}, \mathrm{CH}_{2} \mathrm{OH}, 1 \mathrm{H}\right) 4.99\left(\mathrm{~b}, \mathrm{NCH}_{2} \mathrm{CHOH}, 1 \mathrm{H}\right), 4.33-4.27\left(\mathrm{~m}, \mathrm{NCH}_{2} \mathrm{CHOH}\right.$, $\mathrm{NCH}_{2} \mathrm{CH}_{2} \mathrm{OH}, 4 \mathrm{H}$ ), 3.74 (b, $\mathrm{NCH}_{2}, 2 \mathrm{H}$ ) (in Supplementary Materials Figure S10).

${ }^{13} \mathrm{C}-\mathrm{NMR}\left(\delta \mathrm{ppm}, \mathrm{DMSO}-d_{6}, 100 \mathrm{MHz}\right): 183.67\left(\mathrm{C}_{\text {carbene }} \mathrm{Ag}\right), 141.51$ (ipso carbon aromatic ring), 128.31, 127.72, 126.08 (aromatic carbons), 117.10, 116.74 (backbone carbons), $71.63(\mathrm{CHOH}), 60.28\left(\mathrm{CH}_{2} \mathrm{OH}\right), 56.99\left(\mathrm{NCH}_{2} \mathrm{CHOH}\right), 52.57\left(\mathrm{NCH}_{2} \mathrm{CH}_{2} \mathrm{OH}\right)$ (in Supplementary Materials Figure S11).

ESI-MS $\left(\mathrm{CH}_{3} \mathrm{CN}, \mathrm{m} / z\right): 707.99716$ Dalton attributable to $\left[\mathrm{C}_{26} \mathrm{H}_{28} \mathrm{AgCl}_{4} \mathrm{~N}_{4} \mathrm{O}_{4}\right]^{+}$.

4.2.7. General Procedure for the Synthesis of Gold(I) N-Heterocyclic Carbene Complexes ( $3 b$ and $4 b)$

Following the literature, gold complexes $3 \mathbf{b}$ and $4 \mathbf{b}$ were prepared by trans-metalation route [2-10]. The imidazolium salt $(1.0 \mathrm{eq})$ was reacted with the silver oxide $(0.7 \mathrm{eq})$. The mixture was then filtered and solution was added (chloro(dimethylsulfide)gold (I)) to give gold NHC complexes.

4.2.8. Synthesis of Chloro [ $N$-(2-Hydroxyethyl)- $N^{\prime}$-(2-Hydroxy-2-Phenyl)Ethyl-Imidazole2-Yliden] Gold(I) (3b)

The imidazolium salt S3 (0.500 g; $1.40 \mathrm{mmol})$ and $\mathrm{Ag}_{2} \mathrm{O}(0.202 \mathrm{~g} ; 0.98 \mathrm{mmol})$ were dissolved in dry dichloromethane $(25 \mathrm{~mL})$ containing $4 \AA$ molecular sieves. The mixture was stirred at room temperature with exclusion of light for $4 \mathrm{~h}$. It was then filtered by a pad of Celite to remove the silver iodide byproduct and molecular sieves. Chloro(dimethylsulfide)gold(I) $(0.415 \mathrm{~g}, 1.40 \mathrm{mmol})$ was added to solution and the reaction mixture was stirred for other $4 \mathrm{~h}$, at room temperature under dark conditions. Afterward, the mixture was further filtered to eliminate AgI byproduct. The solution was dried a 
reduced pressure to lead a yellow powder. The residual was washed with diethyl ether obtaining the gold complex $3 \mathbf{b}(0.260 \mathrm{~g}, 0.56 \mathrm{mmol}$, yield: $40 \%)$.

${ }^{1} \mathrm{H}-\mathrm{NMR}\left(\delta \mathrm{ppm}, \mathrm{DMSO}-d_{6}, 400 \mathrm{MHz}\right): 7.40-7.36(\mathrm{~m}$, aromatic hydrogens, $7 \mathrm{H}), 5.81$ $(\mathrm{m} ; \mathrm{CHOH}, 1 \mathrm{H}) 5.08-5.02\left(\mathrm{~m}, \mathrm{NCH}_{2} \mathrm{CH}_{2} \mathrm{OH}, \mathrm{NCH}_{2} \mathrm{CHOH}, 4 \mathrm{H}\right), 3.74\left(\mathrm{~d}, \mathrm{NCH}_{2} \mathrm{CH}_{2}, 2 \mathrm{H}\right)$ (in Supplementary Materials Figure S12).

${ }^{13} \mathrm{C}-\mathrm{NMR}\left(\delta \mathrm{ppm}, \mathrm{DMSO}-\mathrm{d}_{6}, 100 \mathrm{MHz}\right): 168.37\left(\mathrm{C}_{\text {carbene }} \mathrm{-Au}\right), 142.07$ (ipso carbon aromatic ring), 128.30, 127.79, 127.61 (aromatic carbons), 122.33, 121.56 (backbone carbons), $72.36(\mathrm{CHOH}), 60.44\left(\mathrm{CH}_{2} \mathrm{OH}\right), 57.79\left(\mathrm{NCH}_{2} \mathrm{CHOH}\right), 53.00\left(\mathrm{NCH}_{2} \mathrm{CH}_{2} \mathrm{OH}\right)$ (in Supplementary Materials Figure S13).

ESI-MS $\left(\mathrm{CH}_{3} \mathrm{CN}, \mathrm{m} / z\right)$ : 661.20838 Dalton attributable to $\left[\mathrm{C}_{26} \mathrm{H}_{32} \mathrm{AuN}_{4} \mathrm{O}_{4}\right]^{+}$(in Supplementary Materials Figure S14).

4.2.9. Synthesis of Chloro [4,5-Dichloro ( $N$-(2-Hydroxyethyl)- $N^{\prime}$-(2-Hydroxy-2-Phenyl) Ethyl-Imidazole)-2-Yliden] Gold(I) (4b)

At suspension of imidazolium salt S4 $(0.530 \mathrm{~g} ; 1.23 \mathrm{mmol})$ in dry dichloromethane $(25 \mathrm{~mL})$ silver oxide $(0.198 \mathrm{~g}$; $0.861 \mathrm{mmol})$ was added, and the mixture was stirred for $4 \mathrm{~h}$ in dark conditions to give the silver (I) complex. The mixture was filtered to remove the AgI, and the gold precursor $(0.362 \mathrm{~g} ; 1.23 \mathrm{mmol})$ was added to grey solution. The mixture was stirred for other $4 \mathrm{~h}$ in the dark. It was then filtered, and the yellow solution was dried in vacuo, and the gold complex $\mathbf{4 b}$ was obtained after washing with diethyl ether (yield: $61 \%$, corresponding to $0.400 \mathrm{~g}, 0.75 \mathrm{mmol}$ ).

${ }^{1} \mathrm{H}-\mathrm{NMR}\left(\delta \mathrm{ppm}\right.$, DMSO- $\left.d_{6}, 400 \mathrm{MHz}\right): 7.38-7.28(\mathrm{~m}, 5 \mathrm{H}$ aromatic hydrogens), 5.89 (s, $\mathrm{CHOH}, 1 \mathrm{H}), 5.07-4.99\left(\mathrm{~m} ; \mathrm{CH}_{2} \mathrm{OH} ; 2 \mathrm{H}\right) 4.33-4.28\left(\mathrm{~m}, \mathrm{NCH}_{2} \mathrm{CH}_{2} \mathrm{OH}, 2 \mathrm{H}\right), 3.74\left(\mathrm{~d}, \mathrm{NCH}_{2}\right.$, 2H) (in Supplementary Materials Figure S15).

${ }^{13} \mathrm{C}-\mathrm{NMR}\left(\delta \mathrm{ppm}, \mathrm{DMSO}-d_{6}, 100 \mathrm{MHz}\right): 170.90\left(\mathrm{C}_{\text {carbene }}-\mathrm{Au}\right) 141.35$ (ipso carbon aromatic ring), 128.4, 127.94, 125.08 (aromatic carbons), 117.20, 116.74 (backbone carbons), $72.14(\mathrm{CHOH}), 59.85\left(\mathrm{CH}_{2} \mathrm{OH}\right), 56.89\left(\mathrm{NCH}_{2} \mathrm{CHOH}\right), 52.37\left(\mathrm{NCH}_{2} \mathrm{CH}_{2} \mathrm{OH}\right)$ (in Supplementary Materials Figure S16).

ESI-MS $\left(\mathrm{CH}_{3} \mathrm{CN}, \mathrm{m} / z\right)$ : 709.05720 Dalton attributable to $\left[\mathrm{C}_{26} \mathrm{H}_{28} \mathrm{AuCl}_{4} \mathrm{~N}_{4} \mathrm{O}_{4}\right]^{+}$(in Supplementary Materials Figure S17).

4.3. General Procedure for $A^{3}$ Coupling (Aldehyde, Amine, Alkyne) Reaction: General Procedure of $A^{3}$ Coupling Reaction Promoted by M-NHC Catalysts

In a $10 \mathrm{~mL}$ Schlenk tube, the suitable aldehyde $(1.0 \mathrm{mmol})$, piperidine $(1.2 \mathrm{mmol})$, and phenylacetylene $(1.5 \mathrm{mmol})$ were introduced with 2-bromomesytilene as internal standard $(1.0 \mathrm{mmol})$ and the catalyst $(3 \% \mathrm{~mol})$. The reaction mixture was stirred for $6 \mathrm{~h}$ at $80{ }^{\circ} \mathrm{C}$. It was then cooled at room temperature, and $\mathrm{CH}_{2} \mathrm{Cl}_{2}$ was added. The organic phase was dried on magnesium sulfate and filtered. The catalytic activity was evaluated by ${ }^{1} \mathrm{H}-\mathrm{NMR}$, integrating the signal at 6.89 ( $2 \mathrm{H}$ of internal standard) and protons in $\alpha$ to nitrogen atom of propargylic amine, i.e., at $\delta 3.43,2 \mathrm{H}$ for $\mathrm{N}$-(3-phenyl-2-propynyl) piperidine) PAA1; at $\delta 3.11,1 \mathrm{H}$ for 1-(1-cyclohexyl-3-phenyl-2-propynyl) piperidine) PAA2; at $\delta 4.79,1 \mathrm{H}$ for $\mathrm{N}$-(1,3-diphenyl-2-propynyl) piperidine PAA3, respectively. The NMR characterization of coupling products is reported in ref. [41].

\subsection{Antibacterial Activity}

Microbiological Assays and Bacterial Strains

The antimicrobial activity of compounds containing both $\mathrm{Ag}$ and $\mathrm{Au}(\mathbf{1 a}-\mathbf{4 a}$ and $\mathbf{1 b}-\mathbf{4 b}$ ) was estimated by determining the minimal growth inhibitory concentrations (MIC), according to the indications given in the guidelines of the Clinical and Laboratory Standards Institute (CLSI) $[17,22]$. All molecules were tested in the concentration range of $0-150 \mu \mathrm{g} / \mathrm{mL}(0,0.5,1,2,3,4.5,6.5,7.5,10,15,25,40,50,75,100,150)$. Antibacterial compound 1a [40] and pro-ligands S1, S2, S3, S4 were introduced as experimental controls. Briefly, the bacteria were suspended in Luria-Bertani (LB) broth (tryptone, $10 \mathrm{~g} / \mathrm{L}$; yeast extract $10 \mathrm{~g} / \mathrm{L}$; sodium chloride, $5 \mathrm{~g} / \mathrm{L}, \mathrm{pH} 7$ ) at a density of $5 \cdot 10^{5} \mathrm{CFU} / \mathrm{mL}$ and incubated 
in the presence of the different concentrations of each compound at $37^{\circ} \mathrm{C}$, with constant shaking $(250 \mathrm{rpm})$. After $24 \mathrm{~h}$ the effects on growth were evaluated by turbidity, measuring the optical density (OD) at $600 \mathrm{~nm}$. The MIC was defined as the lowest concentration that did not change the turbidity of the sample with respect to time 0 . For each compound, the MIC was repeated in three independent experiments, each in triplicate.

Bacteria used for microbiological assays were Escherichia coli (strain JM109) and the pathogenic Staphylococcus aureus (hospital isolate), representative of Gram negative and Gram positive, respectively. E. coli was purchased from Promega (http:/ / www.promega. $\mathrm{com} /$ products, accessed on 28 October 2021). The S. aureus strain was obtained from the microbial collection deposited in the microbiology laboratory of the University of Salerno directed by Prof. G. Vigliotta.

\subsection{Anticancer Activity}

\subsubsection{Cell Culture}

The cell lines employed in this work (MCF-7, MDA-MB-231, HeLa, MCF-10A, and Hek-293) were purchased from American Type Culture Collection (ATCC, Manassas, VA, USA). MCF-7 and MDA-MB-231 human breast cancer cells were maintained in Dulbecco's modified Eagle's medium/nutrient mixture Ham F-12 (DMEM/F12), supplemented with $5 \%$ fetal bovine serum (FBS, Thermo Fisher Scientific, Milan, Italy) and $1 \%$ penicillin/streptomycin. HeLa human epithelial cervix carcinoma cells were cultured in minimum essential Eagle's Medium (MEM), supplemented with 10\% FBS, 1\% L-glutamine, 1\% penicillin/streptomycin, and $1 \%$ nonessential amino acids (NEAA). MCF-10A human mammary epithelial cells were cultured in DMEM/F12 medium, supplemented with 5\% horse serum (HS, Thermo Fisher Scientific, Milan, Italy), 1\% penicillin/streptomycin, $0.5 \mathrm{mg} \mathrm{mL}^{-1}$ hydrocortisone, $20 \mathrm{ng} \mathrm{mL}^{-1}$ human epidermal growth factor (hEGF), $10 \mathrm{mg} \mathrm{mL}^{-1}$ insulin, and $0.1 \mathrm{mg} \mathrm{mL}^{-1}$ cholera enterotoxin (Sigma-Aldrich, Milan, Italy). Hek-293 human embryonic kidney cells were cultured in DMEM, supplemented with 10\% FBS, 1\% Lglutamine, and $1 \%$ penicillin/streptomycin. Cells were maintained at $37^{\circ} \mathrm{C}$ with $5 \% \mathrm{CO}_{2}$ and periodically screened for contamination.

\subsubsection{MTT Assay}

The in vitro anticancer activity of all of the studied compounds were evaluated using the MTT assay as already described [40]. The treatment was carried out exposing the cells to the target compounds dissolved in DMSO at seven concentrations $(0.1,1,5,10,50,100$, and $200 \mu \mathrm{M})$ for $72 \mathrm{~h}$. MTT (3-(4,5-dimethylthiazol-2-yl)-2,5-diphenyl tetrazolium bromide) was added for $2 \mathrm{~h}$ at $37^{\circ} \mathrm{C}$ (final concentration $0.5 \mathrm{mg} / \mathrm{mL}$ ). The formazan crystals were then dissolved in DMSO, and the optical density was measured at $570 \mathrm{~nm}$ using a microplate reader. All the calculations were performed in triplicate, and the results were represented as the percent (\%) of basal. The $\mathrm{IC}_{50}$ values were calculated using curve fitting GraphPad Prism 9 software (GraphPad Software, La Jolla, CA, USA) with nonlinear regression. The values represent the mean \pm standard deviation $(n=3)$.

\section{Conclusions}

In summary, we prepared silver and gold complexes with NHC ligands of general formula $\left[\mathrm{M}(\mathrm{NHC})_{2}\right]^{+}\left[\mathrm{MX}_{2}\right]^{-}$. The complexes were used as catalysts for the $\mathrm{A}^{3}$-coupling reactions of phenylacetylene, piperidine, and three different aldehydes ( $\mathrm{p}$-formaldehyde, cyclohexanecarboxaldehyde, and benzaldehyde) to afford propargylamines. They showed moderate to high activity. Better performances were recorded with $\mathrm{Au}(\mathrm{I})$ complex $4 \mathrm{~b}$ in the reaction of phenylacetylene and piperidine with $\mathrm{p}$-formaldehyde or cyclohexanecarboxaldehyde.

The antimicrobial activity of complexes $\mathbf{3} \mathbf{a}, \mathbf{b}$ and $\mathbf{4} \mathbf{a}, \mathbf{b}$ was evaluated against Escherichia coli and Staphylococcus aureus as representatives of Gram-negative and Gram-positive bacteria and compared with that of complexes $\mathbf{1} \mathbf{a}, \mathbf{b}$ and $\mathbf{2} \mathbf{a}, \mathbf{b}$. The most active compounds against $E$. coli were the $\mathrm{Ag}(\mathrm{I})$ complexes (MIC values range from $6.5-15 \mu \mathrm{g} / \mathrm{mL}$ ), whereas against $S$. aureus were the $\mathrm{Au}(\mathrm{I})$ complexes (MIC values range from 0.5 to $40 \mu \mathrm{g} / \mathrm{mL}$ ). 
Cytotoxicity of the pro-ligands (S3 and $\mathbf{S 4}$ ) and $\mathbf{3 a}, \mathbf{b}$ and $\mathbf{4 a , b}$ complexes were studied by means of a colorimetric assay (MTT assay) towards two human breast cancer cell lines, namely MCF-7 and MDA-MB-231, and human cervical carcinoma HeLa cells. The lowest inhibitory concentration values were verified for $4 \mathbf{a}\left(\mathrm{HeLa}\right.$ cells, $\left.\mathrm{IC}_{50}=11.9 \pm 0.4 \mu \mathrm{M}\right)$ and $4 \mathrm{~b}\left(\mathrm{MCF} 7, \mathrm{IC}_{50}=12.2 \pm 1.2 \mu \mathrm{M}\right)$.

It is noteworthy to mention that the complexes are highly selective towards cancer cells and bacterial cells. In fact, treatments up to $72 \mathrm{~h}$ with the synthesized complexes do not affect the viability of the normal MCF-10A breast epithelial cells and the embryonic kidney cells Hek-293; moreover, at non-toxic doses for these cells they have high antimicrobial activity.

Supplementary Materials: The following supporting information can be downloaded at: https: / / www.mdpi.com/article/10.3390/catal12010018/s1. Figure S1: ${ }^{1} \mathrm{H}-\mathrm{NMR}$ of S3; Figure S2: ${ }^{13} \mathrm{C}-$ NMR of S3; Figure S3: ESI-MS of S3; Figure S4: ${ }^{1} \mathrm{H}-\mathrm{NMR}$ of S4; Figure S5: ${ }^{13} \mathrm{C}-\mathrm{NMR}$ of S4; Figure S6: MALDI-MS of S4; Figure S7: ${ }^{1} \mathrm{H}-\mathrm{NMR}$ of 3a; Figure S8: ${ }^{13} \mathrm{C}-\mathrm{NMR}$ of 3a; Figure S9: ESI-MS of 3a; Figure S10: ${ }^{1} \mathrm{H}-\mathrm{NMR}$ of $4 \mathbf{a}$; Figure S11: ${ }^{13} \mathrm{C}-\mathrm{NMR}$ of $4 \mathbf{a}$; Figure S12: ${ }^{1} \mathrm{H}-\mathrm{NMR}$ of $\mathbf{3 b}$; Figure S13: ${ }^{13} \mathrm{C}-\mathrm{NMR}$ of $\mathbf{3 b}$; Figure S14: MALDI OF $\mathbf{3 b}$; Figure S15: ${ }^{1} \mathrm{H}-\mathrm{NMR}$ of $\mathbf{4} \mathbf{b}$; Figure S16: $:{ }^{13} \mathrm{C}-\mathrm{NMR}$ of $\mathbf{4 b}$; Figure S17: MALDI of $\mathbf{4 b}$.

Author Contributions: Investigation and Data Curation, M.S.; Writing-Original Draft Preparation, Conceptualization and editing, A.M.; Investigation, G.V.; Formal analysis, J.C.; Data curation, D.I. and M.S.S.; Writing and Review and editing, P.L. All authors have read and agreed to the published version of the manuscript.

Funding: This research received no external funding.

Institutional Review Board Statement: Not applicable.

Informed Consent Statement: Not applicable.

Data Availability Statement: Not applicable.

Acknowledgments: The authors are grateful to Patrizia Oliva and Patrizia Iannece for technical assistance. Furthermore, the authors thank Manuela Iervolino and Ilario Botta who performed some experiments.

Conflicts of Interest: The authors declare no conflict of interest.

\section{References}

1. Nolan, S.P. N-Heterocyclic Carbenes: Effective Tools for Organometallic Synthesis; Wiley-VCH: Weinheim, Germany, 2014.

2. Hopkinson, M.; Richter, C.; Schedler, M.; Glorius, F. An overview of N-heterocyclic carbenes. Nature Cell Biol. 2014, 510, 485-496. [CrossRef] [PubMed]

3. Hahn, F.E.; Jahnke, M.C. Heterocyclic carbenes: Synthesis and coordinantion chemisry. Angew. Chem. Int. Ed. 2008, 47, 3122-3172. [CrossRef] [PubMed]

4. Peris, E. Smart N-heterocyclic carbene ligands in catalysis. Chem. Rev. 2018, 118, 9988-10031. [CrossRef]

5. Díez-González, S.; Marion, N.; Nolan, S.P. N-heterocyclic carbenes in late transition metal catalysis. Chem. Rev. 2009, 109, 3612-3676. [CrossRef]

6. Liu, W.; Gust, R. Update on metal N-heterocyclic carbene complexes as potential anti-tumor metallodrugs. Coord. Chem. Rev. 2016, 329, 191-213. [CrossRef]

7. Patil, S.A.; Patil, S.A.; Patil, R.; Keri, R.S.; Budagumpi, S.; Balakrishna, G.R.; Tacke, M. N-heterocyclic carbene metal complexes as bio-organometallic antimicrobial and anticancer drugs. Future Med. Chem. 2015, 7, 1305-1333. [CrossRef]

8. Hindi, K.M.; Panzner, M.J.; Tessier, C.A.; Cannon, C.L.; Youngs, W.J. The medicinal applications of imidazolium carbene-metal complexes. Chem. Rev. 2009, 109, 3859-3884. [CrossRef]

9. Munoz-Lopez, S.; Couce-Rios, A.; Sciortino, G.; Lledos, A.; Ujaque, G. Mechanistic Insight on the hydration of terminal and interanal allenes catalyzed by [(NHC)Au] ${ }^{+}$. Organometallics 2018, 37, 3543-3551. [CrossRef]

10. Coberàn, R.; Ramirez, J.; Poyatos, M.; Peris, E.; Fernàdez, E. Coinage metal complexes with N-heterocyclic carbene ligands as selective catalysts in diboration reaction. Tetrahedron Asymmetry 2006, 17, 1759-1762. [CrossRef]

11. Ibáñez, S.; Poyatos, M.; Peris, E. Gold catalysts with polyaromatic-NHC ligands. Enhancement of activity by addition of pyrene. Organometallics 2017, 36, 1447-1451. [CrossRef] 
12. Lòpez, S.; Herrero-Gòmez, E.; Pèrez-Galàn, P.; Nieto-Oberhuber, C.; Echavarren, A.M. Gold(I)-catalyzed intermolecular cyclopropanation of enymes with alkenes: Trapping of two different gold carbenes. Angew. Chem. Int. Ed. 2006, 45, 6029-6032. [CrossRef] [PubMed]

13. Zhao, Q.; Meng, G.; Szostak, M.; Nolan, S.P. N-Heterocyclic carbene complexes in C-H activation reactions. Chem. Rev. 2020, 120, 1981-2048. [CrossRef]

14. Lin, J.C.Y.; Huang, R.T.W.; Lee, C.S.; Bhattacharyya, A.; Hwang, W.S.; Lin, I.J.B. Coinage metal—N-heterocyclic carbene complexes. Chem. Rev. 2009, 109, 3561-3598. [CrossRef]

15. Wang, H.M.J.; Lin, I.J.B. Facile synthesis of silver(I)-carbene complexes. useful carbene transfer agents. Organometallics 1998, 17, 972-975. [CrossRef]

16. Wang, Z.; Tzouras, N.V.; Nolan, S.P.; Bi, X. Silver N-heterocyclic carbenes: Emerging powerful catalysts. Trends Chem. 2021, 3, 674-685. [CrossRef]

17. Ramírez, J.; Corberán, R.; Sanaú, M.; Peris, E.; Fernandez, E. Unprecedented use of silver(I) N-heterocyclic carbene complexes for the catalytic preparation of 1,2-bis(boronate) esters. Chem. Commun. 2005, 24, 3056-3058. [CrossRef] [PubMed]

18. Iglesias-Sigüenza, J.; Ros, A.; Díez, E.; Magriz, A.; Vázquez, A.; Álvarez, E.; Fernández, R.; Lassaletta, J.M. C2-Symmetric S/C/S ligands based on $N$-heterocyclic carbenes: A new ligand architecture for asymmetric catalysis. Dalton Trans. 2009, 40, 8485-8488. [CrossRef] [PubMed]

19. Pietro, A.; Fructos, M.R.; Diaz-Requejo, M.M.; Perez, P.J.; Perez-Galan, P.; Delmont, N.; Echavarren, A.M. Gold-catalyzed olefin cyclopropanation. Tetrahedron 2009, 65, 1790-1793.

20. Liu, Q.X.; Hu, Z.L.; Yu, S.C.; Zhao, Z.X.; Wei, D.C.; Li, H.L. NHC Pd (II) and Ag (I) complexes: Synthesis, structure and catalytic activity in three types of C-C coupling reactions. ACS Omega 2018, 3, 4035-4047. [CrossRef] [PubMed]

21. Schneider, S.K.; Herrmann, W.A.; Herdtweck, E. Synthesis of the first gold(I) carbene complex with a gold-oxygen bond-First catalytic application of gold(I) complexes bearing N-heterocyclic carbenes. Z. Anorg. Allg. Chem. 2003, 629, 2363-2370. [CrossRef]

22. Gatto, M.; Belanzoni, P.; Belpassi, L.; Biasiolo, L.; Del Zotto, A.; Tarantelli, F.; Zuccaccia, D. Solvent-, silver-, and acid-free NHC-Au-X catalyzed hydration of alkynes. The pivotal role of the counterion. ACS Catal. 2016, 6, 7363-7376. [CrossRef]

23. Gatto, M.; Baratta, W.; Belanzoni, P.; Belpassi, L.; Del Zotto, A.; Tarantelli, F.; Zuccaccia, D. Hydration and alkoxylation of alkynes catalyzed by NHC-Au-OTf. Green Chem. 2018, 20, 2125-2134. [CrossRef]

24. Peshkov, V.A.; Pereshivko, O.P.; Nechaev, A.A.; Peshkov, A.A.; Van der Eycken, E.V. Reactions of secondary propargylamines with heteroallenes for the synthesis of diverse heterocycles. Chem. Soc. Rev. 2018, 47, 3861-3898. [CrossRef] [PubMed]

25. Bayrakdar, T.A.C.A.; Nahra, F.; Davis, J.V.; Gamage, M.M.; Captain, B.; Temprado, M.; Marazzi, M.; Saab, M.; Van Hecke, K.; Ormerod, D.; et al. Dinuclear gold(I) complexes bearing alkyl-bridged bis( $N$-heterocyclic carbene) ligands as catalysts for carboxylative cyclization of propargylamine: Synthesis, structure, and kinetic and mechanistic comparison to the mononuclear complex [Au(IPr)Cl]. Organometallics 2020, 39, 2907-2916. [CrossRef]

26. Malka, M.; Gimeno, M.C.; Visbal, R. Recent review on biological role of Au-NHC complexes: Recent advances in gold-NHC complexes with biological properties. Chem. Soc. Rev. 2019, 48, 447-462.

27. Johnson, N.A.; Southerland, M.R.; Youngs, W.J. Recent review on medicinal application of Ag-NHC: Recent developments in the medicinal applications of silver-nhc complexes and imidazolium salts. Molecules 2017, 22, 1263. [CrossRef] [PubMed]

28. Barillo, D.J.; Marx, D.E. Silver in medicine: A brief history BC335 to present. Burns 2014, 40, S3-S8. [CrossRef]

29. Balfourier, A.; Kolosnjaj-Tabi, J.; Luciani, N.; Carn, F.; Gazeau, F. Gold-based therapy: From past to present. Proc. Natl. Acad. Sci. USA 2020, 117, 22639-22648. [CrossRef]

30. McNally, J.J.; Youngman, M.A.; Dax, S.L. Mannich reactions of resins-bound substrates: 2. A versatile three-component solid-phase organic synthesis methodology. Tetrahedron Lett. 1998, 39, 967-970. [CrossRef]

31. Dyatkin, A.B.; Rivero, R.A. The solid phase synthesis of complex propargylamines using the combination of Sonogashira and Mannich reactions. Tetrahedron Lett. 1998, 39, 3647-3650. [CrossRef]

32. Peshkov, V.A.; Pereshivko, O.P.; Van der Eycken, E.V. A walk around the A3-coupling. Chem. Soc. Rev. 2012, $41,3790-3807$. [CrossRef] [PubMed]

33. Lauder, K.; Toscani, A.; Scalacci, N.; Castagnolo, D. Synthesis and reactivity of propargylamines in organic chemistry. Chem. Rev. 2017, 117, 14091-14200. [CrossRef]

34. Baranyi, M.; Porceddu, P.F.; Gölöncsér, F.; Kulcsár, S.; Otrokocsi, L.; Kittel, Á.; Pinna, A.; Frau, L.; Huleatt, P.B.; Khoo, M.-L.; et al. Novel (hetero)arylalkenyl propargylamine compounds are protective in toxin-induced models of Parkinson's disease. Mol. Neurodegener. 2016, 11, 6. [CrossRef] [PubMed]

35. Do Carmo Carreiras, M.; Ismaili, L.; Contelles, J.M. Propargylamine-derived multi-target directed ligands for Alzheimer's disease therapy. Biorg. Med. Chem. Lett. 2020, 30, 126880-126895. [CrossRef]

36. Hickey, J.L.; Ruhayel, R.A.; Bamard, P.J.; Baker, M.V.; Berners-Price, S.J.; Filipovska, A. Mitochondria-targeted chemotherapeutics: The rational design of gold(I) $N$-heterocyclic carbene complexes that are selectively toxic to cancer cells and target protein selenols in preference to thiols. J. Am. Chem. Soc. 2008, 130, 12570-23571. [CrossRef] [PubMed]

37. Mariconda, A.; Sirignano, M.; Costabile, C.; Longo, P. New NHC-silver and gold complexes active in A3-coupling (aldehydealkyne-amine) reaction. Mol. Catal. 2020, 480, 110570. [CrossRef] 
38. Saturnino, C.; Barone, I.; Iacopetta, D.; Mariconda, A.; Sinicropi, M.S.; Rosano, C.; Campana, A.; Catalano, S.; Longo, P.; Andò, S. $\mathrm{N}$-heterocyclic carbene complexes of silver and gold as novel tools against breast cancer progression. Future Med. Chem. 2016, 8 , 2213-2229. [CrossRef] [PubMed]

39. Iacopetta, D.; Rosano, C.; Sirignano, M.; Mariconda, A.; Ceramella, J.; Ponassi, M.; Saturnino, C.; Sinicropi, M.S.; Longo, P. Is the way to fight cancer paved with gold? Metal-based carbene complexes with multiple and fascinating biological features. Pharmaceuticals 2020, 13, 91. [CrossRef]

40. Napoli, M.; Saturnino, C.; Cianciulli, E.I.; Varcamonti, M.; Zanfardino, A.; Tommonaro, G.; Longo, P. Silver(I) N-heterocyclic carbene complexes: Synthesis, characterization and antibacterial activity. J. Organomet. Chem. 2013, 725, 46-53. [CrossRef]

41. Arnold, P.L.; Rodden, M.; Davis, K.; Scarisbrick, A.C.; Blake, A.; Wilson, C. Asymmetric lithium(I) and copper(II) alkoxy-Nheterocylic carbene complexes; crystallographic characterization and Lewis acid catalysis. Chem. Commun. 2004, 14, 1612-1613. [CrossRef]

42. Arnold, P.L.; Liddle, S.T. F-block N-heterocyclic carbene complexes. Chem. Comm. 2006, 38, 3959-3971. [CrossRef]

43. Iacopetta, D.; Mariconda, A.; Saturnino, C.; Caruso, A.; Palma, G.; Ceramella, J.; Muià, N.; Perri, M.; Sinicropi, M.S.; Caroleo, M.C.; et al. Novel gold and silver carbene complexes exert antitumor effects triggering the reactive oxygen species dependent intrinsic apoptotic pathway. Chem. Med. Chem. 2017, 12, 2054-2065. [CrossRef] [PubMed]

44. Garrison, J.C.; Youngs, W.J. Ag(I) N-heterocyclic carbene complexes: Synthesis, structure, and application. Chem. Rev. 2005, 105, 3978-4008. [CrossRef] [PubMed]

45. Mariconda, A.; Grisi, F.; Costabile, C.; Falcone, S.; Bertolasi, V.; Longo, P. Synthesis characterization and catalytic behavior of palladium bearing a hydroxy-functionalized N-heterocyclic carbene ligand. New J. Chem. 2014, 38, 762-769. [CrossRef]

46. Costabile, C.; Mariconda, A.; Sirignano, M.; Crispini, A.; Scarpelli, F.; Longo, P. A green approach for A3-coupling reactions: An experimental and theorical study on NHC silver and gold catalysts. New J. Chem. 2021, 45, 18509-18517. [CrossRef]

47. Abbiati, G.; Rossi, E. Silver and gold-catalyzed multicomponent reactions. Beilstein J. Org. Chem. 2014, 10, 481-513. [CrossRef]

48. Document M07National Committee for Clinical Laboratory Standards. Methods for Dilution Antimicrobial Susceptibility Tests for Bacteria that Grow Aerobically, Approved Standard, 11th ed. CLSI: Wayne, PA, USA, 2011.

49. Vigliotta, G.; Giordano, D.; Verdino, A.; Caputo, I.; Martucciello, S.; Soriente, A.; Marabotti, A.; De Rosa, M. New compounds for a good old class: Synthesis of two $\beta$-lactam bearing cephalosporins and their evaluation with a multidisciplinary approach. Bioorg. Med. Chem. 2020, 28, 115302. [CrossRef] 